\title{
How Satan and the Devils plan to harm and humiliate mankind: Data from the Quran and Teachings of Prophet Muhammed
}

\author{
Hamza Cherifi (Corresponding author) \\ Faculty of Letters and Foreign Languages, Khemis Miliana University \\ Temmamra City, El Amra, 44010, Ain Defla Province; Algeria \\ 00213776194476 E-mail: h.cherifi@univ-dbkm.dz
}

\begin{abstract}
As treaties for safe conduct and attentive life undertaking, the Quran and teaching of Prophet Muhammed account for what poses dangers to man. Just as other variables in our lives are described and explained, the two sources equally tackle the nature of hostility and adversary against mankind, locating it in Satan and his sinister plans and pointing to the primacy of guarding against Satanic agendas. In what follows, I expose the tactics deployed by Satan and the Devil to harm humans and divert them from wellbeing in all its escalations. Towards this direction I tracked the words 'Satan' and 'Devils' in the corpora of ClearQuiran and SUNNAH in order to identify regularities and group concepts under categories.
\end{abstract}

Keywords: Satan; Devil; Mankind; Enemy; Plan

DOI: $10.7176 / \mathrm{JPCR} / 50-10$

Publication date:November $30^{\text {th }} 2020$

\section{A Common Enemy to Mankind}

Of all things standing against man's wellbeing and happiness, the Quran and Teaching or Prophet Muhammed (henceforth Sunnah) warn humans most against Satan and his Devil followers: "...do not follow the footsteps of Satan. He is to you an open enemy" (Quran 2:168), an enemy stiff determination for misguiding and hurting mankind. Satan's utmost aim is to harm humanity in general by all possible means. This hatred is rooted to envy for humans as creatures with great bounties and favor: we have honored man. It is also because humans-on their pure, uncontaminated status--are assigned the task of spreading justice on earth, the reason why each and every one of us feels that it is up to him or her to protect and care of not only oneself, but also other humans, other species, and even the entire universe. This default quest of good inside us is what really define us as unquestionably unique creatures, and it is what causes brutal animosity from Satan and his followers with constant, vigilant and holistic taking on all aspects of our lives, in dinner, impregnation, or even in our dreams, all with the aim of sparking complete discomfort: "Satan appears at everything done by you; he appears even at one's dinner"; "Bad dreams are from Satan" (Sunnah); "If anyone intends to have (sexual intercourse) with his wife, he should say: '...O Allah! Keep us away from Satan and keep Satan away from what you have bestowed upon us)"' (Sunnah). Satan is one ruthless, typically anti-mankind entity seeking to indulge all humans in all sorts of suffering and grief: " No child is born but he is pricked by Satan and he begins to weep because of the pricking of Satan" (Sunnah). It is even that "random looks in prayers are something Satan snatches from one's prayer" (Sunnah). Literally or not, "the Devil flows in our bodies just like blood" (Sunnah) in bodily and spiritual impediments.. The fact that Satan comes with this big threat to humans explains why his animosity and cunning are central in Islamic teaching. It is also the reason why humans are advised to say: "I seek refuge to Allah from Satan" at the start practice. This phrase has the attraction of reminding humans of Satan's ambushing evil and the likelihood of interference in all engagements and thoughts "(Sunnah).

\section{Fighting Naturalness}

In the quest for an overall discomfort of humans, Satan sets out to cripple naturalness and tangibility in diverse escalations. This is quite evident in words of Satan himself as revealed in the Quran: "And I will mislead them, and I will entice them, and I will prompt them to slit the ears of cattle, and I will prompt them to alter the creation of God" (Quran 5:119). This follows that naturalness offers comfort and compatibility with man as an equally natural entity. It also follows that humans are efficiently completed, healed and strengthened by naturalness in all forms. Therefore, Satan seeks to distort and deform the true nature of all things and offer alternatives with 
devastating mismatch. Satan executes this plan targeting a number of aspects. Denaturalization in all forms causes danger and improper space for humans to navigate and interact with, leading to. This explains why Satan's war against nature and originality is this tough and brutal. In fact, the notion changing the creation has a wide range of forms and aspects, but the scope of the present paper does not allow a thorough tackling of the issue. But, essentially, it is about deforming and altering the true, original nature of almost everything on our space with the aim of devising an incompatible space for humans.

In the same vein Satan seeks to promote loneliness and detachment from others in fragile individualism: "A single rider is a devil, and a pair of riders are a pair of devils, but three are a company of riders" (Sunnah). This follows that collectivism ensures collaboration, strength and sound consciousness: "The Allah is with the group" (Sunnah).

\section{Disseminating Mischief}

Satan fights stability as it is the incentive that allows humans to safely execute all the actions necessary for wellbeing. Unstable, predatory vicinity makes it hard for mankind to live naturally and effectively put into practice ideations meant to benefit and generate welfare in diverse embodiments. Diseases, injustice, oppression, wars, and unnatural immorality represent cruel interrupters of safe, stable recourse of life. This situation makes humans much struggling with hardships and inconvenient, instead of safely enjoying and investing what life offers in respect and instinctive dignity. To achieve this goal of spoiling life - and dragging mankind to depression, sorrow and hopelessness-Satan sets out to triple a number of factors ensuring a life crammed with unrest.

Central to this outlined agenda is the dissemination of inter-humans hostility by sparking and propagating division among humans: "Satan has lost all hopes that the worshippers would ever worship (him) in the peninsula of Arabia, but he (is hopeful) that he would sow the seed of dissension amongst them" (Sunnah), and This explains why there is so much division and unrest in Arab countries. Satan and his followers know well that division opens up hostility, hatred, racism, and dogma which, in turns, engineer and regulate wars and rivalries in diverse forms (political, military, economic, cultural, etc.). As steps towards this direction, Satan deploys a number of strategies, namely urging humans to hate and focus on each other's faults: "Satan wants to provoke strife and hatred among you through intoxicants and gambling, and to prevent you from the remembrance of God, and from prayer. Will you not desist?" (Quram 5:91).

It is about getting humans fighting and ceaselessly guarding themselves against each other, with fear, panic and discomfort being constant: "That is only Satan frightening his partisans; so do not fear them, but fear me if you are believers. (Quran 3:175).

Backing up oppressive regimes is another Satanic practice with the aim of instigating injustice, discrimination and poverty: "Satan promises you poverty (Quran 2:268). These latter factors deprive us of comfort, rest and happiness. On the other scale, they sow sadness, depression and a tastelessness of life: "Sorrow comes from Satan" (Quran 58:10). An oppressed society results renders individuals occupied with mere peace and earning of one's living, than with knowledge and self-promotion. Satan fights knowledge, the free-thinking mind, and all the factors needed for their inhabitation. Conversely, Satanism works to standardize ignorance, blind mindedness and fake understandings. All this is expected to serve the objective of decentring constructive, remedial and promoting minds which stands against the Satanic desire to bring about crisis, failure and sufferings.

Another way mischief is established is through dragging to immorality:"Satan urges you to immorality" (Quran $2: 268)$, in the sense that man becomes "seduced by the devils" (6:71), all with the aim of devising a shameless, instinct-led society wherein the man's dignity and honored spirit are spoiled.

Adding to the provocation of immorality, Satan works to estrange and alienate legal, instinctive relations and the notion of raising generations within warm and lovely families. All this goes within the agenda of devising an incoherent society full of divorce, division and carelessness, betrayal and discontinuation: "... he strives to spread corruption on earth, destroying properties and lives..." (Quran 2:205) in other words Satan's aim is the construct of an animalistic societies crammed with unrest, decency, or even worse than animals, so that Satan relegate humans to the worst of all creatures: "Like animals or even worse" (Quran 25:44) in oppression, aggression, selfishness, greed and extravagance: "The extravagant are brethren of the devils" (Quran 7:27), the reason why God makes it clear: "O you who believe! Intoxicants, gambling, idolatry, and divination are abominations of Satan's doing. Avoid them, so that you may prosper (5: 90); "Satan sows discord among them" (Quran 17:53).

Equally important in Satan's plan is the propagation of failure and laziness, which all carves poverty and passivism. Satan discards hard work and activism: "He who slept throughout the night till the morning is a man in whose ears Satan urinated" (Sunnah). The reason why Prophet Muhammad orders movement and active engagement in life: "Movement is blessing"; "Just move and you will earn your living". This would relieve 
independency and achieve self-saturation and prosperous society, which Satan wants not to see.

At another level, Satan works so that humans do not take proper decision and clear understanding of the nature of things. By this, Satan aims at deviate mankind from all that is sound and accurate. In so doing, Satanic philosophy encourages haste, anger and inconsiderate thinking: "Haste comes from Satan" (Sunnah); "Anger comes from Satan" (Sunnah). The expected outcome is misguidance, negligence, wrong accusation as well as inaccurate incentive of principles, treatments and practices. Also, Satan's mechanism is flowing humans with ill ideas meant to result in the conduct of bad, improper behavior and in the embrace of wrong convictions about oneself, others and about the nature of things.

\section{Further Clarification}

Satan uses other humans to run sinister plans: “...when they are alone with their devils, they say, "We are with you; we were only ridiculing" (Quran 2:14). Those are the "allies of the Devil" (Quran 4:79) or "the soldiers of Satan" (26:95). Hence, individuals are Satanic, and so are their practices and ideas which, in their deep level, bear Satan's touch and cunning. For this, we need to critically subsume ideas and practices under the Satanic test, looking for whether flowing and encountered ideas and acts align with the outlined sinister agendas meant to misguide, serotype, spark conflict and divisions and propagate all that is sinister and against the wellbeing and comfort of all humans regardless their differences. It is well to remember that these sinister practices often disguise in good, they often carve out an illusion of a better reality, usually beginning with an attempt to demonize what is useful, relevant and really beneficial to us, with the aim of dragging humans to tricky alternatives running against instinct, naturalness and the free-thinking mind: "Satan made their deeds appear alluring to them" (Quran $16: 63)$.

These alternatives are often ascribed propagated embellishing properties, while all that is good and compatible with humans gets distorted and deformed so that we refrain from it. That is the essence in the philosophy of Satan - man's harshest enemy — in his war against man. It is about decorating evil and demonizing good so that humans suffer and enjoy not what has been presented to them by Allah.

It is worth noting that Satan, the Devils and other devilish humans exact their utmost to camouflage this war so that humans initiate no resistance and counter practices. Satan seeks to make humans unconscious and inattentive about the fact that on the view that forgetting the enemy is. In so doing, Satan and his followers devises other sources of hostility, namely the ever-launched idea that the enemy of humans is nothing other than another human, while, in fact, all humans have a common enemy that they should guard themselves against and resist.

This is the biggest trick that Satan has been playing, a trick that deprived us the enjoyment of knowing and living with each other in harmony and exploitation of the endless things bringing us together, and in appreciation of difference and variety which mark richness and multiplicity, not-as Satan seeks to portray-avenues for disagreement, incompatibility and resentment. Unfortunately, we have not been perceiving difference as multiheaded, variant token for effective encounter with life challenges, or for solid, comprehensive moves for battling common threats. The trick that difference denotes rivalry did trigger and aggravate deadly struggles prompted by horrifying selfishness and greed, by an unbelievably unquestioned fear from the Other despite the countless chances for harmony and collectiveness. These muffled and contested mindsets are the triggers of pacific, collaborative and common- sense practices bringing the connectedness and prosperity of mankind at large, which Satan and his followers fight in determination and rage. Our difference is rather a chance for us to complete and support each other for, and to fight the boredom and tastelessness. For that reason Satan seeks to iron out cultures by propagating Universalism and fight our specificities.

As a result of this implemented agenda, we rarely tend to remember and recall Satan's hostility, even an attemptlike the present paper - to outline and roll out the Satan's plans goes rarely encountered.

\section{Going Anti-Satanic, Anti-Evil}

Our acts must run counter to Satan's acts and features as counter-satanic acts contest and resent all that harms both humans and the compatible space they patrol. The practice of anti-Satanism should be guiding and regulating our deeds and thoughts in a much more guided and vigilant quest for the wellbeing inherent in natural choices. One has to make sure that one is going ant-Satanic by a conducting anti-Satanic check of attitudes and behaviors. Because the features characterizing Satan must be distractive to humans, the Quran and Teaching of Prophet Muhammed warn humans against behaving in a way similar to Satan, emphasizing the need for revered practices at a number of counts, involving manners and attitudes: "Do not eat with your left hand, because Satan eats and drinks with his left hand" (Sunnah); "The sneeze is from Allah and the yawn is from Satan. So when one of you yawns let him cover his mouth with his hand" (Sunnah); "When one of you sees a bad dream let him blow three 
times on his left and say, 'I seek refuge in Allah from the Satan' three times and change the side on which he was lying"; (Sunnah); "No person should eat and drink with his left hand for Satan eats with his left hand and drinks with his left hand" (Summah); "Do not turn your houses into graveyards" (Sunnah); "Satan runs away from the house in which Chapter Al-Baqarah ( is recited" (Sunnah).

The following recommendations also falls within the conduct of ant-Satanic practices: "When a man enters his house and mention Allah's name on entering and on his food, the devil says: 'You have no place to spend the night and no evening meal', but when he enters without mentioning Allah's name on entering, the devil says: 'You have found a place to spend the night', and when he does not mention Allah's name at his food, he says: "You have found a place to spend the night and an evening meal"' (Sunnah); "The devil was created of fire, and fire is extinguished only with water; so when one of you becomes angry, he should perform ablution" (Suunah); "There should be bedding for a man, bedding for his wife, and third for a guest, but a fourth for the devil" (Sunnah); Spitting, blowing one's nose, menstruating and drowsiness during the prayer are from Satan" (Sunnah); "The black dog is a devil" (Sunnah).

Similarly, subsequent clarifications are meant to raise humans' awareness of Satan's tactics, and hence to trigger counter, defensive measures: "When the wings of the night (spread) or it is night, restrain your children (from going out), for the Satan is abroad at that time, and when a part of the night is passed, free them and shut the doors. making mention of God's name, for the Satan does not open a closed door; and tighten the (mouths of waterskins and mention the name of Allah, cover your utensils and mention the name of Allah even though you should just put something on them, and extinguish your lamps" (Sunnah); "None of you should fail to say, when he enters his toilet: 'O Allah, I seek refuge with You from the filthy and impure, the evil one with evil companions, the accursed Satan"' (Sunnah): "If one of you goes angry, he should say, "I seek refuge to Allah from Satan"” (Sunnah); "If you keep silent and control yourself when being insulted, an angel is sent to invalidate all accusations, but if you take revenge, a devil would come down" (Sunnah); "Satan comes to everyone of you and says: 'Who created this and that?' till he questions: 'Who created your Lord?'. When he comes to that, one should seek refuge in Allah and keep away (from such idle thoughts)" (Sunnah); When Satan hears the call to prayer, he runs away to a distance like that Rauha--of thirty-six miles away" (Sunnah).

The next passages show more the tactics and strategies deployed by Satan and unveil his representations: "None amongst you should point a weapon towards his brother, for he does not know that Satan might cause the weapon (to slip) from his hand and (he may injure anyone) and thus he may fall into Hell-Fire" (Sunnah); "Satan ties three knots at the back of your head when you sleep. If you wake up and remember Allah, a knot is untied. If you do $w u d u$ (ablution), a knot is untied. If you pray, a knot is untied, and morning finds you lively and in good spirits, and if not, morning finds you in bad spirits and lazy" (Sunnah); "Indeed, Satan does not enter the house in which Chapter Al-Baqarah is recited" (Sunnah); "Allah is with the judge as long as he is not unjust. So when he is unjust, He leaves him and he is attended by Satan" (Sunnah); "Leaving the house, if a person says: 'I begin with the Name of Allah; I trust in Allah; there is no altering of conditions but by the Power of Allah', it will be said to him: 'You are guided, defended and protected'. The devil will go far away from him" (Sunnah).

\section{Final Notes}

The fact, however, remains, that Satan's plans and cunning are nothing terrifying or uncontested: "Truly the Satan's plans are fragile and vulnerable" (Quran 5:76), and all that is planned and done by Satan goes not outside the will and supervision of Allah. Just like other creatures, Satan is a creation of Allah, however with special knowledge and awareness of Allah's all-power and all-wisdom. Satan himself recognizes his fear of and subjection to Allah: "Like the devil, when he says to the human being, 'Disbelieve'. But when he has disbelieved, he says, "I am innocent of you; I fear God, the Lord of the Worlds'" (Quran 59:16). What rather makes Satan go disobedient and anti-mankind is envy, animosity: "I won't bow down before someone you created from mud" (Quran 17: 61). In other part, Allah uses Satan as a test for mankind, seeing whether humans are faithful and obedient to the instructions effecting wellbeing. The victory against Satan is bound up with adhering to the instructions and warnings of Allah: "We said, 'Go down, some of you enemies of one another"' (Quram 2:36), "Yet whenever guidance comes to you from Me, then whoever follows My guidance - they have nothing to fear, nor shall they grieve" (Quran 2:38). We have to bear in mind that some humans are Satanic and Devilish, believing in the necessity of executing Satanic plans and truly acting on behalf of Satan:"The devils inspire their followers to argue with you" (Quran 6:121); "They seek Satanic sources for legislation, in spite of being commanded to reject them" (Quran 4:60); "We have made the devils friends of those who do not believe" (Quran 7:27); "They have adopted the devils for patrons rather than God, and they assume that they are guided" (Quran 7:30); "O my father, do not worship the devil" (Quran 19:44). All this, “...but Satan promises them nothing but delusions"(Quran 4:120). 
And Satan will say, when the issue is settled, "God has promised you the promise of truth, and I promised you, but I failed you. I had no authority over you, except that I called you, and you answered me. So do not blame me, but blame yourselves. I cannot come to your aid, nor can you come to my aid. I reject your associating with me in the past. The wrongdoers will have a torment most painful (Quran 14:22).

\section{References}

Itani, T. (n.d). Quran. https://www.clearquran.com

SU NNAH.COM Project. (n.d). Hadiths of prophet muhammed. https://www.sunnah.com

\section{Notes}

The two main sources of this work are classic references, and hence they are not applicable to the author-date slots in the in-text citations.

\section{Acknowledgement:}

I would like to acknowledge the support of my teacher, Bel Abbes Neddar. 